\title{
Determinants of Audit Report Lag and Corporate Governance in Malaysia
}

\author{
Kogilavani Apadore ${ }^{1} \&$ Marjan Mohd Noor ${ }^{2}$ \\ ${ }^{1}$ Faculty of Business \& Finance, Universiti Tunku Abdul Rahman, Perak, Malaysia \\ ${ }^{2}$ School of Business, Al-Bukhary International University, Kedah, Malaysia \\ Correspondence: Kogilavani Apadore, Faculty of Business \& Finance, Universiti Tunku Abdul Rahman, \\ Malaysia. E-mail: kogie_85@yahoo.com
}

Received: February 5, 2013

Accepted: May 22, 2013

Online Published: July 12, 2013

doi:10.5539/ijbm.v8n15p151

URL: http://dx.doi.org/10.5539/ijbm.v8n15p151

\begin{abstract}
Inevitably, an accurate and timely financial statement contributes enormously to the success of many organizations. Therefore, accuracy and availability about financial information is vital for investors and shareholders in order to ease their decision making process. This paper aims to analyze the relation between the characteristics of corporate governance; board independence, ownership concentration, audit committee independence, expertise, meeting, size, internal audit investment and audit report lag among companies listed under Bursa Malaysia. The samples covered are among 180 companies listed at Bursa Malaysia for 2009 and 2010. The samples were chosen randomly from 843 companies, the population. Descriptive statistics have been used to provide better perception of the length of time needed by an auditor, to complete an audit. The results show that in average, the companies took about 100 days to complete their audit report with maximum and minimum days of 148 days and 26 days respectively. In addition, regression analysis was used to provide empirical evidence on which variables had strong bonding with audit report lag. The outcomes elicit that audit committee size, ownership concentration; organization size and profitability are significantly associated with audit report lag. However the other six variables (audit committee independence, meetings, expertise and types of auditors) were found to have insignificant relationship with audit report lag.
\end{abstract}

Keywords: audit lags, corporate governance, audit committee, internal audit investment

\section{Introduction}

\subsection{Background of the Study}

Timeliness is really a prevalent and pertinent issue that exists in corporate reporting since a few decades ago. Timeliness enhances the usefulness of information or otherwise it will decrease its economic value. It is parallel with recognition that made by American Accounting Association (AAA, 1955 and 1957), the Accounting Principles Board (1970) and the American Institute of Certified Public Accountants (1973). Moreover, audit report lag leads the existing shareholders and potential shareholders to postpone their transaction on shares $(\mathrm{Ng}$ and Tai, 1994). Thus, it will trigger a negative effect on the company and in order to subdue the audit report lags, reliable and timely accounting information are really needed as a catalyst to create confidence among investors. Generally producing timely reliable financial reports helps to build trust and confidence in governance. However, delayed reporting can reduce the relevance, reliable and usefulness of the information reported which tends to diminish the trust of potential investors. The paper inquires into association among characteristics of corporate governance, existence of audit committee such as audit committee independence, expertise, frequencies of meeting and internal audit investment by using data from Bursa Malaysia for the year 2009 and 2010.

Thus, this study may appear to be an extension of all areas carried out earlier. Nonetheless the prime purpose is to look for more evidence for the year 2009 and 2010 from Bursa Malaysia. The aims of this study are to gain knowledge into internal audit investment, corporate governance characteristic and audit committee. Indeed, most of the prior studies are solely concentrated on audit committee or corporate governance characteristics or both variables. This study combines the existence of audit committee (audit committee independence, expertise, meeting and size), characteristic of corporate governance and internal audit investment. However, the primary goal of this study is to measure effects from existence of internal audit investment on audit report lag in which 
the variables and considered still infant for this field.

Thus from the discussion, the question arises whether characteristics of corporate governance really contribute to the lag of the audit reports among companies listed at Bursa Malaysia or not?

\subsection{Research Question}

1) What is the status of audit report lag of companies listed at Bursa Malaysia

2) What is the impact of implementing corporate governance mechanism on audit report lag in Malaysian listed companies?

3) What is the effect of internal audit investment on audit report lag?

\section{Literature Review \& Hypothesis Development}

In order to get a vivid understanding on this study, this paper reviews and highlights relevant studies from established scholars and researchers.

\subsection{Audit Report Lag}

Presently, investors play a role similar to an accountant in order to obtain timely financial information. Consequently auditors will be under pressure in order to produce audited annual report or financial statement on time. It must be noted that research in this field have been conducted from various perspectives by looking from all angles more than 30 years ago in countries like New Zealand by Courtis (1976) and Gilling (1977), Davies and Whittred (1980) in Australia, Garsombke (1981), Givolvy and Palmon (1982), Chambers and Penman (1984), Ashton, Willingham and Elliott (1987), Atiase, Bamber and Tse (1988) in United States, Ashton, Graul and Newton (1989) in Canada.

In the year 2011, Hashim and Abdul Rahman carried out a research on how does audit report lag affects the effectiveness of audit committee especially in Malaysian Listed Companies. The outcomes of this study proved that audit committee independence and expertise could be as an intermediator as to reduce audit lag in Malaysia. The findings by Afify (2009) showed that the board independence, duality of CEO, and existence of audit committee have a significant effect on audit report lag but ownership concentration has an insignificant effect on ARL. In addition, Trauringana (2008) found that there are significant negative relationships between corporate governance mechanisms (proportion of finance experts on the audit committee (PFAC), frequency of board meetings (FBM), and dual language reporting (DULR)) and timeliness of audit report.

\subsection{Agency Theory}

As per agency theory, certain factors came to the surface. Evidently, the audit committee does play an inarguable role where they need to monitor and report the progress in the companies . Nonetheless, this theory has identified the close inter-relationship of the principal and its delegates being work hand in hand with another party that is the agent. Based on corporation context, the owners are considered as a principal meanwhile the directors are the agent.

Agency theory is considered as a relevant theory which is applicable to this study because it explains the board of directors, director's ownership and audit committee, whereby each of them is functioning as a monitor of mechanism to reduce agency problems. Monitoring mechanism refers to the corporate governance practises, the proper management performance and financial reporting processes (Nelson and Shukeri, 2011).

\subsection{Transaction Cost Economics}

Sad to say, synthesis that has been conducted by researchers like Boyle (1993) and Spraakman (1997) in their studies is not going adequate consideration to the part played by transaction cost economics.Itcannot be denied the usefulness of transaction cost economics in undertaking the operation cost of companies and this in fact is of great assistance to the manger1990. As Penno (1990) justify this concept as to how internal audit findings can be very objective as and when the hierarchy of the organization is made aware off.

\subsection{Characteristics of Corporate Governance}

It is mandatory on the part of corporate governance to ascertain about efficiency and effectiveness of the affairs of the company to enhance the interests of safeguarding in the companies particularly and the shareholders at large. To do so in an exemplary manner the owner's responsibility is delegated to the audit committee. (www.bursamalaysia.com, 2011).

\subsection{Audit Committee Independence}

The agency theory helps the independent members in audit committee to monitor the agent's activities and 
reduce from withholding information. It is because audit committee with more independent directors are considered as a more reliable group other than board of directors in monitoring the company (Hashim and Abdul Rahman, 2011). An effective role of audit committee would be able to privilege all the stakeholders of a company. As required by Section 344A (2) of the Bursa Malaysia Listing Requirement, audit committee must have minimum three members and majorly of them must be non-executive directors.

Furthermore, there are some studies that have been conducted in relation between audit committee independence and financial reporting practices. The findings by Klein (2002) shows there is a negative relationship between independent audit committee and earning management which suggested that independent audit committee members are effective in controlling earning management practices. However, according to Kirk (2000), justified the hypothesis by emphasis and the goals of audit committee are to give accurate reviews on financial information while audit committee independent can lead to the trustable reports on financial. Hence, the first hypothesis to be tested is:

\section{$\mathrm{H}_{1}$ : There is a positive relationship between audit committee independence and audit report lag.}

\subsubsection{Audit Committee Meeting}

The audit committee meetings is obviously concerned as the right platform for directors to discuss the financial reporting process of monitoring financial reporting matters (Mohamad-Nor et al, 2010). However, the frequencies of meetings may reflect the activeness of audit committee in assessing internal control and it may also respond to the emergence of problems (Krishnan, 2005). Audit committee must carry out activities effectively through an increased frequency of meeting in order to maintain its control functions (Bedard et al., 2004).

Mohamad-Nor et al., (2010) have investigated the relation between an audit committee that meets at least quadruple a year and audit report lag. It seems obvious that audit committee meeting is the right platform to ensure that all principles and rules are adhered to in the carrying out of all financial commitments by the respective organizations. The more often they meet to find out the course effect of the present time lag the better it could be (at least quadruple times in a year as dictated in the Bursa Malaysia Corporate Governance Guide 2009). This leads to the next hypothesis, which is:

\section{$\mathrm{H}_{2}$ : There is a positive relationship between audit committee meetings and audit report lag.}

\subsubsection{Audit Committee Expertise}

Another important factor and believe is that the audit committee comprises expertise well-versed in the understanding and operation of the task entrusted to them so that it's easier to identified error and communicate with external auditors. This could avoid any form of doubts arising from the parties concerned regarding the sincerity in the perpetual preparation and submission of such reports. Audit committee expertise is important in order to deal effectively with external auditors; it is because audit committee often act as the mediator between the management and auditors (Hashim and Abdul Rahman., 2011). Abbott and Parker (2004) findings showed there is relationship existing between financial reporting restatement and fraud.The chances of terminating and auditor who issued a going-concerned report should be reduced, especially in the existence of audit committee with better governance and financial expertise (Carcello and Neal, 2003). Hence the third hypothesis to be tested is:

\section{$\mathrm{H}_{3}$ : There is a positive relationship between audit committee expertise and audit report lag.}

\subsubsection{Audit Committee Size}

The number of audit committee members has been well spelt out by Bursa Malaysia to appoint among the directors and must be not less than three members. It has been pointed out by Mohamad-Nor et al. (2009), the size should be optimal enough to work efficiently so that the eventual result will be a genuine report highlighting all the important components and produce the report on time. On the other hand, Bedard and Gendron (2010) had opinioned that the size and composition of the audit committee did not matter much. Saleh et al. (2007) had also had also concurred with much a view that the size does matter to have significant effect on the monitoring of earning management. Therefore, the next hypothesis:

\section{$\mathbf{H}_{4}$ : There is a negative relationship between audit committee size and audit report lag.}

\subsubsection{Board Independence}

With reference to board independence, Yaacob and Che-Ahmad (2010) in their studies had found a positive relationship leading to delay in auditing with a p-value of 0.030 , meaning presence of independent management requires higher quality of financial statements and a good quality audit. This study appears to agree with Afify 
(2009) who come out with a very close relationship between ARL and independence of the board in Egypt. The fifth hypothesis is thus:

\section{$\mathrm{H}_{5}$ : There is a negative relationship between board independence and audit report lag.}

\subsubsection{Internal Audit Investment}

Internal audit department is in fact used essential to provide the necessary feedback to the external auditors. Primarily, internal audit will exist in each and every company as to minimize the burdens that experienced by external auditors in the company. It is on par with perception of most public listed companies whereby they conceived internal audit as a tool to integrate corporate governance regime of their companies. Internal audit's goals fundamentally are known to evaluate the company's risk management, internal control and corporate governance processes to be functioned correctly and adequately. Based on Haron et al. (2004), he asserted that external auditors can rely on internal auditor's comments regarding on control systems and company's operations. This is because he reiterated that internal auditor's works have potential to reduce time consumption that needed to be spent on the audit tasks and shorten audit delays. It is on par with study of Pizzini et al. (2011) where they found firms with highly experienced internal audits significantly have shorter audit delays. Even though, internal auditors focused distinctively on their host financial reporting process but there is still lack of researches on the effects of internal auditing on companies external financial reporting as stated by Prawitt (2010). Thus, the following can be stated as sixth hypothesis, which is:

\section{$H_{6}$ : There is a negative relationship between internal audit investment and audit report lag.}

\subsubsection{Ownership Concentration}

Ashton et al. (1987) and Bamber et al. (1993) advocated that companies tend to experience longer audit report lag if the level of manager ownership is greater due to the less pressures being impose to external auditors and they might already have access to the required information. However, Gilling (1977) found a negative relationship and reported that too much of pressures being imposed on external auditors to complete the report in a very short duration in order to obtain information on time.

Ishak et al. (2010) found that the ownership of a company's shares is more closely and tightly held by a few internal shareholders relative compared to the shares held by outside shareholders. Since higher acceptable audit risk allows the auditor to reduce the extent and amount of work performed before completing the audit, such companies therefore are expected to experience relatively shorter audit delays. Based on the previous discussion, the following seventh hypothesis is proposed

\section{$\mathrm{H}_{7}$ : There is a positive relationship between ownership concentration and audit report lag.}

\section{Method}

The study used a secondary data which are retrieved from trusted source suchlike company's complete annual reports. The sample consists of 100 companies listed at Bursa Malaysia (www.bursamalaysia.com) for 2009 and 2010. The samples were chosen randomly from 843 companies of the population. The companies listed under Bursa Malaysia were selected for this study because they are governed by the rules and regulations imposed by Malaysia Code of Corporate Governance and Malaysia Listing Requirements. Annuals reports of 2009 and 2010 were chosen specifically because of several changes that have been made in the revised Malaysian Code of Corporate Governance (MCCG) through the revision of MCCG (2007). However, the final sample derives as follows:

Table 1. Sample selection

\begin{tabular}{lc}
\hline & $\mathrm{N}$ \\
\hline Total companies listed under Bursa Malaysia as at 12/1/2012 & 843 \\
Randomly chosen & $(200)$ \\
Available information on internal audit function & 134 \\
\hline
\end{tabular}

The audit report lag model used in this study are adapted from prior studies (Bamber et. al., 1993; Leventis et al.,2005; Afify, 2009; Mohamad-Nor et.al., 2010; Hashim and Abdul Rahman, 2011). The audit report lag model for this study is as follows:

$$
\begin{gathered}
A R L=\beta_{0}+\beta_{1} A C I N D+\beta_{2} A C M E E T+\beta_{3} A C E X P+\beta_{4} A C S I Z E+\beta_{5} B I N D+\beta_{6} I N T A U N+\beta_{7} O W N C O N+\beta_{8} \\
\text { SIZE }+\beta_{9} A U D T Y P E+\beta_{10} P R O F+\varepsilon
\end{gathered}
$$


where $\beta_{0}$, the constraints coefficient of regression; $\beta_{1}-\beta_{7}$ regression coefficiencies of Corporate Governance variables ( Independent Variables ); $\beta_{8}-\beta_{10}$ coefficiencies of control variables; $\varepsilon$, random error term.

Table 2. Summary of variables measurement

\begin{tabular}{ll}
\hline Variables name & Definitions \\
\hline Dependent Variable & \\
ARL & Audit report lag \\
Independent variables & \\
OWNCON & Ownership concentration \\
INTAUIN & Internal Audit Investment \\
BIND & Board independence \\
ACIND & Audit Committee Independence \\
ACMEET & Audit Committee Meetings \\
ACEXP & Audit Committee Expertise \\
AC SIZE & Audit Committee Size \\
Control variables & \\
SIZE & Organizational size \\
AUDIT TYPE & Types of Auditors \\
PROF & Profitability \\
\hline
\end{tabular}

\section{Results}

\subsection{Descriptive Statistics}

Table 3. Descriptive Statistics for audit report lag $(\mathrm{N}=180)$

\begin{tabular}{lllcccc}
\hline Year & & N & Minimum & Maximum & Mean & Median \\
\hline 2009 & ARL & 90 & 26 & 148 & 98.43 & 107.50 \\
2010 & ARL & 90 & 47 & 125 & 101.31 & 109.50 \\
$2009-2010$ & ARL & 180 & 26 & 148 & 99.87 & 108.50 \\
\hline
\end{tabular}

Notes: ARL $=$ number of days between the end of the fiscal year end to the date of completion of the audit report.

According to the above table, the mean score of audit report lag for the pooled sample is 100 days with a maximum and minimum day of 148 days and 26 days respectively. This shows that the companies took about 100 days averagely to complete their audit report. Mohamad-Nor et.al., (2010) asserted in their study that the if the audit report lag is took 19 days to 332 days respectively, it can be said that audit report lag is shorter.

Table 4. Number of companies and audit report lag for $2009 \& 2010$

\begin{tabular}{lcccc}
\hline \multicolumn{1}{c}{ Audit Report Lag } & No. of & \multicolumn{2}{c}{ No. of } \\
\hline ARL (within) Year/ Percentage & Companies 2009 & Percent (\%) & Companies 2010 & Percent (\%) \\
\hline 1 month (30 days) & 1 & 1.11 & 0 & 0 \\
2 months (60 days) & 14 & 15.56 & 8 & 8.89 \\
3 months (90 days) & 15 & 16.67 & 13 & 14.44 \\
4 months (120 days) & 56 & 62.22 & 66 & 73.33 \\
5 months (150 days) & 4 & 4.44 & 3 & 3.33 \\
Total & 90 & 100 & 90 & 100 \\
\hline
\end{tabular}

By using the pooled sample of $2009 \& 2010$, the result indicated that the companies did comply with Bursa Malaysia Listing Requirement with few exceptions. The result of this study is similar with Hashim and Abdul Rahman (2011) which discovered that on average the companies took about 103 days to complete the annual reports. This result is also similar with Afify (2009) result which has found that the maximum 114 days needed 
to complete the annual report. Corroboratively, Che-Ahmad and Abidin (2008), mentioned that it took approximately 116 days for companies to produce their complete activities throughout the preceding year. In addition, the finding result of Mohamad-Nor et., al (2010) is almost in line with current study, whereby the author documented that Malaysian listed companies need about 3 months to publish reports of company's audit activities after the fiscal year ended.

Nevertheless, when compared with the audit report lags in other countries such as the Athens taken 97.56 days (Leventis, 2005), New Zealand 87.7 days (Carslaw and Kaplan, 1991), USA 59.36 days (Lee et al., 2009), Canada 54 days (Newton and Ashton, 1989), the mean period of ARL among Malaysia companies seems to be longer. The reason could be due to the Listing Requirement stated under Malaysia Code of Corporate Governance.

Table 4 shows the number of companies and audit report lag for the year 2009 and 2010. It shows that only one company (ICAPITAL.BIZ BHD) managed to complete its annual report within 30 days The result also indicated that $96 \%$ of the companies completed and submitted their annual report within 4 months; which showed that all the companies issued their annual report within 2 months earlier than the Bursa Malaysia requirements. According to the chapter 9 paragraph/rule 9.23 of Bursa Malaysia Listing Requirements, all listed companies are mandated to issue their yearly report within biannual from the end of the fiscal year.

The results show that one company have managed to complete and submitted their annual report within a month as compared to Hashim and Abdul Rahman, (2011) found that there is no one company which managed to issue annual report within a month. They examine the annual report of 288 companies listed at Bursa Malaysia for a three year period from 2007 to 2009. This shows that companies are getting more efficient and more concerned to issue annual reports as early as possible in order to share information with public especially investors. However, the result shows that all the companies managed to complete and submitted their annual reports within 5 months, which means a month ahead of the speculated time and this suggest that the companies realized the importance and the level of usefulness among the users especially the investors in order to make decisions. The result supported opinion that over delay financial statements will affect uncertainy in making investment decisions (Hashim and Abdul Rahman, 2011; Ahmad and Kamarudin 2003; Ashton et al., 1987).

Table 5. Descriptive statistic

\begin{tabular}{lccccc}
\hline \multicolumn{1}{c}{ Independent Variables } & $\mathrm{N}$ & Minimum & Maximum & Mean & Std. Deviation \\
\hline ACIND & 134 & 40 & 100 & 86.05 & 16.864 \\
ACMEET & 134 & 1 & 9 & 4.93 & 1.281 \\
ACEXP & 134 & 0 & 2 & 0.94 & 0.559 \\
ACSIZE & 134 & 2 & 7 & 3.28 & 0.630 \\
BIND & 134 & 0.25 & 1.00 & 0.4596 & 0.13701 \\
INTAUN & 134 & 7.82 & 18.04 & 11.3778 & 1.65221 \\
OWNCON & 134 & 0 & 7 & 2.93 & 1.533 \\
Control Variables & & & & 19.2324 & .33621 \\
SIZE & 134 & 16.14 & 23.20 & .61 & .489 \\
AUDTYPE & 134 & 0 & 1 & .0429 & .15444 \\
PROF & 134 & -0.54 & 1.02 & & 28.25 \\
Dependent Variables & & & & & 24.639 \\
ARL & 134 & 26 & 148 & & \\
Valid N (listwise) & 134 & & & & \\
\hline
\end{tabular}

Table 5 presents the descriptive statistics of independent and control variables of this study. The result presents the characteristics of audit committee among the public listed companies in Malaysia. The results show that 87 percent of audit committee members are non-executive and independent audit committee members. This result is in line with paragraph 15.11 of the Listing Requirement, audit committee must be non-executive directors with a majority independent.

Table 5 also displays the results of the number of audit committee meetings (ACMEET) held, were 5 meetings held on average during a year. This indicates that all the audit committee in the listed companies discharge their responsibility and plays their duties appropriately. This result is similar with the findings of Hashim and Abdul Rahman (2011). The maximum number of audit committee meetings held during the two years period was 9 times. Chapter 2 of Malaysian Code of Corporate Governance requisite that a minimum, the audit committee 
should at least meet quadruple in a year either on quarterly basis or audit committee may regulate its own procedure. There are only 6 companies (3.33 percent) that do not comply with the listing requirement and almost 97 percent of the companies at least held for audit committee meeting in a year.

Table 5 shows the mean score of audit committee expertise (ACEXP) is 0.94 which is equal to 94 percents. This result indicates that most of the audit committee members in the public listed company have background experience in financial reporting and poses professional qualification such as MIA, MICPA, ACCA, CPA etc. This shows majority of the companies comply with the code of corporate governance which require audit committee members need to be well versed in financial knowledge with at least 1 member who is expert in financial field as requisite under the listing requirement of paragraph 15.10. Perhaps, 36 of the companies formed their audit committee members who does not have professional qualifications or with financial expertise.

In this study, the average size of audit committee is 3.28 people, which is closely related with Mohamad-Nor et al., (2010), Saleh, et al., (2007), who documented on average size of 3.51 and 3.7 people respectively. The minimum number of audit committee member is 2 people while the maximum number of audit committee member is 7 people.

The results also show that 45.9 of the board directors are independent directors (BIND). This result is slightly higher than which was obtained by Yaacob and Che-Ahmad (2012), Abdullah et al. (2010) and Mohomad-Nor et al., (2010) which is 40 percent and 43 percent. This results indicate that the number of independent board of directors are increasing consistently and in line with the Bursa Malaysia listing requirement which required at least one- third of the board of directors shall consists of independent non- executive directors. Table 5 also shows the log of internal audit investment which is 11.38 on average.

Table 5 also shows on average 30 percent of shareholders owning five percent share and above. The maximum number of shareholder owning 5 percent shares and above is 7 people, in which only two companies have no shareholder owning 5 percent shares. The mean for the log total assets (SIZE) is 19.23, which is in line with the findings of Yaacob\&Che-Ahmad (2012). They reported the mean for the total assets has 19.68. 59 percent of the sample companies are audited by Big 4 audit firms (AUDTYPE). This result is in line with Hashim and Abdul Rahman (2011) who have documented that 58 percent of their sample companies are audited Big 4 audit firm. However according to one of the current study on audit in Malaysia by Yaacob\&Che-Ahmad (2012) reported 64.8 percent of the observations are audited Big 4 auditors. The table also shows that ROA (PROF) on average is 0.04, which is quite similar to the findings Hashim and Abdul Rahman (2011) reported the mean of profitability has 0.03 . The table also shows that ROA (PROF) on average is 0.04 , which is quite similar to the findings of Hashim and Abdul Rahman,(2011) who reported that the mean of profitability has 0.03 . Therefore, we could expect similar results of this control variable (SIZE, AUDITYPE and ROA) on audit report lag.

Table 6. Pearson correlation

\begin{tabular}{|c|c|c|c|c|c|c|c|c|c|c|c|c|}
\hline & & ARL & ACIND & $\begin{array}{l}\text { ACM } \\
\text { EET }\end{array}$ & $\begin{array}{l}\mathrm{ACE} \\
\mathrm{XP}\end{array}$ & ACSIZE & BIND & $\begin{array}{l}\text { INTA } \\
\text { UN }\end{array}$ & $\begin{array}{l}\text { OWN } \\
\text { CON }\end{array}$ & SIZE & $\begin{array}{l}\text { AUDT } \\
\text { YPE }\end{array}$ & PROF \\
\hline \multirow[t]{4}{*}{ ARL } & Pearson & 1 & .073 & -.009 & .040 & $-.180 *$ & -.032 & .009 & $.203 *$ & $-.239 * *$ & -.098 & $-.268 * *$ \\
\hline & Correlation & & & & & & & & & & & \\
\hline & Sig. (2-tailed) & & .401 & .920 & .647 & .038 & .715 & .913 & .019 & .005 & .261 & .002 \\
\hline & $\mathrm{N}$ & 134 & 134 & 134 & 134 & 134 & 134 & 134 & 134 & 134 & 134 & 134 \\
\hline $\mathrm{ACIN}$ & Pearson & .073 & 1 & .041 & -.123 & $-.309 * *$ & $.386^{* *}$ & .061 & -.019 & .121 & -.037 & -.166 \\
\hline \multirow[t]{3}{*}{$\mathrm{D}$} & Correlation & & & & & & & & & & & \\
\hline & Sig. (2-tailed) & .401 & & .636 & .158 & .000 & .000 & .481 & .827 & .163 & .674 & .056 \\
\hline & $\mathrm{N}$ & 134 & 134 & 134 & 134 & 134 & 134 & 134 & 134 & 134 & 134 & 134 \\
\hline $\mathrm{ACM}$ & Pearson & -.009 & .041 & 1 & .005 & .107 & -.022 & .074 & .143 & $.220^{*}$ & -.078 & -.116 \\
\hline \multirow[t]{3}{*}{ EET } & Correlation & & & & & & & & & & & \\
\hline & Sig. (2-tailed) & .920 & .636 & & .956 & .219 & .801 & .393 & .099 & .011 & .371 & .182 \\
\hline & $\mathrm{N}$ & 134 & 134 & 134 & 134 & 134 & 134 & 134 & 134 & 134 & 134 & 134 \\
\hline ACEX & Pearson & .040 & -.123 & .005 & 1 & .090 & -.159 & -.021 & .074 & .086 & -.058 & .160 \\
\hline \multirow[t]{3}{*}{$\mathrm{P}$} & Correlation & & & & & & & & & & & \\
\hline & Sig. (2-tailed) & .647 & .158 & .956 & & .302 & .066 & .813 & .394 & .325 & .506 & .065 \\
\hline & $\mathrm{N}$ & 134 & 134 & 134 & 134 & 134 & 134 & 134 & 134 & 134 & 134 & 134 \\
\hline ACSI & Pearson & $-.180 *$ & $-.309^{* *}$ & .107 & .090 & 1 & $.181 *$ & -.158 & .004 & $.196^{*}$ & .082 & .157 \\
\hline \multirow[t]{3}{*}{$\mathrm{ZE}$} & Correlation & & & & & & & & & & & \\
\hline & Sig. (2-tailed) & .038 & .000 & .219 & .302 & & .036 & .068 & .965 & .023 & .347 & .070 \\
\hline & $\mathrm{N}$ & 134 & 134 & 134 & 134 & 134 & 134 & 134 & 134 & 134 & 134 & 134 \\
\hline
\end{tabular}




\begin{tabular}{|c|c|c|c|c|c|c|c|c|c|c|c|c|}
\hline \multirow[t]{4}{*}{ BIND } & Pearson & -.032 & $.386 * *$ & -.022 & -.159 & $.181^{*}$ & 1 & .044 & $-.223^{* *}$ & .132 & -.063 & -.050 \\
\hline & Correlation & & & & & & & & & & & \\
\hline & Sig. (2-tailed) & .715 & .000 & .801 & .066 & .036 & & .614 & .010 & .130 & .468 & .563 \\
\hline & $\mathrm{N}$ & 134 & 134 & 134 & 134 & 134 & 134 & 134 & 134 & 134 & 134 & 134 \\
\hline INTA & Pearson & .009 & .061 & .074 & -.021 & -.158 & .044 & 1 & .042 & .026 & -.089 & -.104 \\
\hline \multirow[t]{3}{*}{ UN } & Correlation & & & & & & & & & & & \\
\hline & Sig. (2-tailed) & .913 & .481 & .393 & .813 & .068 & .614 & & .627 & .763 & .304 & .233 \\
\hline & $\mathrm{N}$ & 134 & 134 & 134 & 134 & 134 & 134 & 134 & 134 & 134 & 134 & 134 \\
\hline OWN & Pearson & $.203 *$ & -.019 & .143 & .074 & .004 & $-.223 * *$ & .042 & 1 & -.064 & -.065 & .031 \\
\hline \multirow[t]{3}{*}{$\mathrm{CON}$} & Correlation & & & & & & & & & & & \\
\hline & Sig. (2-tailed) & .019 & .827 & .099 & .394 & .965 & .010 & .627 & & .465 & .455 & .719 \\
\hline & $\mathrm{N}$ & 134 & 134 & 134 & 134 & 134 & 134 & 134 & 134 & 134 & 134 & 134 \\
\hline \multirow[t]{4}{*}{ SIZE } & Pearson & $-.239 * *$ & .121 & $.220^{*}$ & .086 & $.196^{*}$ & .132 & .026 & -.064 & 1 & $.197^{*}$ & .092 \\
\hline & Correlation & & & & & & & & & & & \\
\hline & Sig. (2-tailed) & .005 & .163 & .011 & .325 & .023 & .130 & .763 & .465 & & .022 & .292 \\
\hline & $\mathrm{N}$ & 134 & 134 & 134 & 134 & 134 & 134 & 134 & 134 & 134 & 134 & 134 \\
\hline AUDT & Pearson & -.098 & -.037 & -.078 & -.058 & .082 & -.063 & -.089 & -.065 & $.197 *$ & 1 & .092 \\
\hline \multirow[t]{3}{*}{ YPE } & Correlation & & & & & & & & & & & \\
\hline & Sig. (2-tailed) & .261 & .674 & .371 & .506 & .347 & .468 & .304 & .455 & .022 & & .292 \\
\hline & $\mathrm{N}$ & 134 & 134 & 134 & 134 & 134 & 134 & 134 & 134 & 134 & 134 & 134 \\
\hline \multirow[t]{4}{*}{ PROF } & Pearson & $-.268^{* *}$ & -.166 & -.116 & .160 & .157 & -.050 & -.104 & .031 & .092 & .092 & 1 \\
\hline & Correlation & & & & & & & & & & & \\
\hline & Sig. (2-tailed) & .002 & .056 & .182 & .065 & .070 & .563 & .233 & .719 & .292 & .292 & \\
\hline & $\mathrm{N}$ & 134 & 134 & 134 & 134 & 134 & 134 & 134 & 134 & 134 & 134 & 134 \\
\hline
\end{tabular}

*. Correlation is significant at the 0.05 level (2-tailed).

**. Correlation is significant at the 0.01 level (2-tailed).

\section{Correlation analysis}

Table 4 shows the correlation matrix for the specified model. None of the variables are correlated above 0.8 (Nunally,1978) which suggested that minimal multicollinearity is not a threat. Also one-to-one relationship between audit report lag and hypothesis variable yield similar result are in regression analysis (see the section on regression analysis).

\subsection{Regression Analysis}

Table 7. Multiple regressions

\begin{tabular}{|c|c|c|c|c|c|c|}
\hline $\begin{array}{c}\text { Hypothesis and } \\
\text { variables }\end{array}$ & B & $\begin{array}{c}\text { Standard } \\
\text { Error }\end{array}$ & B & $\mathbf{T}$ & Sig. & VIF \\
\hline (Constant) & 173.611 & 32.439 & & 5.352 & .000 & \\
\hline H1 ACIND & .070 & .143 & .049 & .490 & .625 & 1.520 \\
\hline H2 ACMEET & 1.018 & 1.648 & .053 & .618 & .538 & 1.112 \\
\hline HЗ АCEXP & 4.040 & 3.486 & .097 & 1.159 & .249 & 1.053 \\
\hline H4 ACSIZE & -5.324 & 3.713 & -.141 & -1.434 & $.154 * *$ & 1.438 \\
\hline H5 BIND & 8.628 & 16.946 & .050 & .509 & .612 & 1.449 \\
\hline H6 INTAUN & -.663 & 1.191 & -.047 & -.556 & .579 & 1.055 \\
\hline H7 OWNCON & 2.102 & 1.287 & .138 & 1.633 & $.105^{* *}$ & 1.069 \\
\hline H8 SIZE & -3.707 & 1.533 & -.215 & -2.419 & $.017^{* * *}$ & 1.183 \\
\hline H9 AUDTYPE & -1.631 & 4.035 & -.034 & -.404 & .687 & 1.075 \\
\hline H10 PROF & -35.359 & 13.355 & -.227 & -2.648 & $.009^{* *}$ & 1.096 \\
\hline
\end{tabular}

Notes: $\mathrm{R}^{2}=0.178$, adjusted $\mathrm{R}^{2}=0.111$; Variables are defined in Table $4.5 ; * * *, * *$ represent statistical significant at the $1 \%, 5 \%$ and $10 \%$ levels respectively (2-tailed).

$\mathrm{ACIND}=$ percentage of non-executive directors to the total of audit committee members.

ACMEET $=$ number of audit committee meeting.

ACEXP $=$ no of audit committee member with background experience in financial reporting.

ACSIZE $=$ number of audit committee members. 
$\mathrm{BIND}=$ proportion of independent directors on board.

INTAUN $=$ natural log of total audit investment.

OWNCON $=$ percentage of company shares held by largest five owners.

$\mathrm{SIZE}=$ natural $\log$ of total assets.

AUDITPE = ' 1 ' if audited by Big-4, ' 0 ' if otherwise.

PROF $=$ net income divided with total assets.

Table 7 exhibits the multiple regression results. The adjusted $\mathrm{R}^{2}$ for this model is $11 \%$ which is quite similar with Mohamad-Nor et al., (2010), Raja Ahmad and Kamarudin (2003) and Henderson and Kaplan (2000) of $16 \%, 14 \%$, and $13 \%$ respectively. The above table also shows the variance inflation factor (VIF) which presents that all variables have a value below than 1.6 which is within the acceptable range of 10 and indicates that multicollinearity is not a major problem (as suggested by Hair, Tatham and Black 1995). Furthermore, this shows that the regression model has significant explanatory power to reveal the results. The result is consistent with Leventis et al. (2005).

$H 1$ expects a positive relationship between audit committee independent and audit report lag. The findings support this hypothesis but it does not significantly relate to the audit report lag. This is consistent with the findings of Henderson and Kaplan, (2000) who found insignificant (-0.417). However, the outcomes from the following prior studies are contrary with Leventis et al. (2005) and Afify (2009). Based on theoretical argument, when independent audit committees demand for higher quality audit, it will be triggered to many collusion of audit delay. The study was unable to find any prima facie evidence to support such variable.

H2 predicts a positive relationship between audit committee meetings and the audit report lag. The result does not support the above hypothesis. The reason for positive and insignificant result could be due to the fact that more issues tend to arise as more meetings are held by the company which prolongs the audit report lag. The findings of this study is similar with Hashim and Abdul Rahman (2011) who reported that audit committee meeting is not significantly associated with the audit report lag. According to the author, the frequency of meetings does not necessarily provide better monitoring efforts to the company. This result is also similar with the findings of Ismail et al. (2008) as explained in the literature review. However, this result is in contrast with prior researches such as Mohamad-Nor et al. (2010).

$H 3$ expects a greater association between the audit committee expertise and the audit report lag. The variable of interest, (ACEXP), is found to be in positively insignificant relationship with the audit report lag. This indicates that there is no association between the audit committee expertise and the audit report lag. As the sample of companies in this study shows a low proportion of directors with an accounting or a finance knowledge background, then it is speculated that it tends to lengthen the audit report lag. However, this result contradicts with the findings of Hashim and Abdul Rahman, (2011) and Bamber et al. (1993).

H4 expects insignificant between audit committee size and audit report lag. It indicates that there is a relationship between audit committee size and audit report lag. This implies that companies with large number of audit committee would exert some pressures or demands on the management and hence faster audit report. As mentioned by Mohamad-Nor et al. (2010), there are potential problems in the financial reporting process which are more likely to be uncovered and unresolved with a larger audit committee.

H5 expects a weak association between board independence between audit report lag. It shows strong association with audit report lag, but not significant. This may mean that the more independent board, it tend to be as an impetus for problem such as arguments or feud because of the different opinions and suggestions and this will prolong the audit report lag. This result is similar with one of the current study by Yaacob and Che-Ahmad (2012) who reported a positive relationship with audit delay but the variables were significantly associated. Besides, this result also in line with the study conducted by Mohamad-Nor et al. (2010) who documented the proportion of independent directors on the board (BIND) has a weak positive relationship with audit lag. However this result is in contrast with Bamber et al. (1993).

H6 expects insignificant results between internal audit investments and audit report lag. Although the relationship is negative, but there was no any support for a significant association between internal audit investment and audit report lag. These results indicate that internal audit does not constitute to reduce the burden of external auditor and also does not shorten the audit report lag. It might be because the greater the internal audit investment, the larger the scope of audit tend to be. This also requires additional effort to be hired by 
external auditors. This situation will prolong the audit report lag.

$H 7$ predicts a positive relationship between ownership concentration and audit report lag. This variable was found to have an insignificant positive relationship between ownership concerntration and ARL. The findings is similar to prior studies (Jaggi \& Tsui, (1999) ; Henderson \& Kaplan (2000); Leventis et al. (2005) and Afify (2009) who have reported that even though the variables are insignificant, but considered they reached the sign of expectations. The result may mean the more number of shareholders owing five percent and above, could lead to increase the demand for higher quality of audit, whereby this situation require external auditors to do a lot of job and this will prolong the audit report lag. Furthermore, large shareholders have greater responsibilities to monitor management and tend to influence the company.

$H 8$ predicts weak association between organization size and audit report lag. The findings support this hypothesis and provide evidence that organization size is significantly related with ARL. This result is in line prior studies (Jaggi \& Tsui, (1999); Afify, (2009); Mohamad-Nor et al. (2010); Hashim and Abdul Rahman, 2011). The findings of current studies indicate that organization size is associated with shorter lag. Bigger firms would be able to establish competent account department, hire bigger audit firms and may have been in business for quite some time and as such would have better record keepings to facilitate audit process. All these help faster the audit. It is noteworthy that Ayoib and Shamharir, (2000) mentioned that larger firm tend to increase audit delays. In contrast, this could be due to the complexity of business that would outweigh the previous arguments. This result was found as expected previously.

$H 9$ predicts a negative relationship between type of auditors and audit report lag. The study fails to find supports for $H 9$. The result contradicts Afify, (2009) who found a positive relationship and also stated that there is no support for significant relationship between types of auditors and ARL. While the result of Leventis et al. (2005) is in line with current study, indicates that a negative relationship exists between the type of auditors and ARL.

H10 predicts a negative relationship between profitability and audit report lag. The findings support this hypothesis and provide evidence that the profitability of a company associated with ARL at the 0.01 or $1 \%$ level. The result is on par with most of the prior literatures such as Ashton et al. (1989), Afify, (2009) and Hashim and Abdul Rahman, (2011). Companies may also want to announce good news quickly and thus would expedite the statutory audit process. This is especially true if the management themselves own some good portion of shares as their wealth would be an impetus for future research. Nevertheless the outcome of Leventis et al. (2005) was recorded that no significant association has been found between profitability and the ARL.

\section{Conclusion}

This study consists of three objectives. The first objective is to investigate the status of audit report lag among public listed companies from 2009 to 2010 . The average duration that needs by external auditor to audit company's accounts is 100 days with minimum of 26 days and maximum of 148 days. Whereby, this result shows that the companies did comply with Bursa Malaysia Listing Requirement with few exceptions as discussed in detailed under chapter four.

Overall, an objective of this study is to probe the relationship of characteristics of corporate governance, existence of audit committee; internal audit investment in audit report lag among public listed company. Through regression analysis, the outcomes show that only two independent variables, audit committee size and ownership concentration are mainly influencing audit report lag and corporate governance in public listed companies of Malaysia. However, the results also show that audit committee independence, meeting, expertise and board independence do not play crucial role in audit report lag. In addition, two control variables of the study, organizational size and profitability have significant impact on audit report lag and by this, we can conclude that tendency of quickly releasing financial reporting is motivated by profitability of a company. However, types of auditors are not significant which is consistent with most of the prior studies.

Many studies have investigated audit report lag by using the characteristics of corporate governance and audit committee effectiveness but it is very rare case for researcher to use internal audit investment. The result of this study shows that there is no significant relationships were found between internal audit investment and audit report lag even though the study has obtained the excepted sign. In which, this indicates that internal audit does not constitute to reduce the burden of external auditor and also does not shorten the audit report lag. It might be because the greater the internal audit investment, the larger the scope of audit tend to be. This acquires additional effort to be hired by external auditors. This situation will prolong the audit report lag.

In a nutshell, the results are consistent with $H 4, H 7, H 8$ and $H 9$ but $H 1, H 2, H 3, H 5$ and $H 10$ are not supported. Perhaps the finding of this study provides more insight into audit report lag by taking into consideration all the 
variables. However this study has also confronted a variety of limitation such as time constraint, limited sample size, and limited disclosure of information on internal audit investment. Therefore future studies are suggested to overcome those limitations.

\section{References}

Abott, L. J., \& Parker, S. (2000). Auditor selection and audit committee characteristics. Auditing: A Journal of Practice \& Theory, 19(Fall), 47-66. http://dx.doi.org/10.2308/aud.2000.19.2.47

Adams, M. B. (1994). Agency theory and the internal audit. Managerial Auditing Journal, 8, 8-12. http://dx.doi.org/10.1108/02686909410071133

Afify, H. A. E. (2009). Determinants of audit report lag: Does implementing corporate governance have any impact? Empirical evidence from Egypt. Journal of Applied Accounting Research, 10(1), 56-86. http://dx.doi.org/10.1108/09675420910963397

Ahmad, R. A. R., \& Kamarudin, K. A. (2003). Audit delay and the timeliness of corporate reporting: Malaysian evidence. Working Paper, MARA University of Technology, Shah Alam.

American Accounting Association. (1957). Accounting and Reporting Standards for Financial Statements and Preceding Statements and Supplements, Sarasota.

American Institute of Certified Public Accountants. (1973). Objectives of Financial Statements. New York.

Ashton, R. H., Graul, P. R., \& Newton, J. D. (1989). Audit delay and timeliness of corporate reporting. Contemporary Accounting Research, 5(2), 657-673. http://dx.doi.org/10.1111/j.1911-3846.1989.tb00732.x

Ashton, R. H., Willingham, J. J., \& Elliott, R. K. (1987). An empirical analysis of audit delay. Journal of Accounting Research, 25(2), 275-292. http://dx.doi.org/10.2307/2491018

Atiase, R. K., Bamber, L. S., \& Tse, S. (1988). Timeliness of financial reporting, the firm size effect, and stock price reactions to annual earnings announcements. Contemporary Accounting Research, 5(2), 526-552. http://dx.doi.org/10.1111/j.1911-3846.1989.tb00722.x

Ayoib, C. A., \& Shamharir, A. (2000). The determinants of audit delay in Malaysia. School of Accountancy. University Utara Malaysia. Working Paper Series.

Bamber, E. M., Bamber, L. S., \& Schoderbek, M. P. (1993). Audit structure and other determinants of audit reporting: An empirical analysis. Auditing: A Journal of Practice and Theory, 12(1), 1-23.

Beasley, M. S., Carcello, J. V., Hermason, D. R., \& Lapides, P. D. (2000). Fraudulent financial reporting: Consideration of industry traits and corporate governance mechanisms. The Accounting Horizons, 14(4), 441-454. http://dx.doi.org/10.2308/acch.2000.14.4.441

Bédard, J., \& Gendron, Y. (2010). Strengthening the financial reporting systems: Can audit committees deliver? International Journal of Auditing, 14(2), 1-37.

Bédard, J., Chtourou, S. M., \& Courteau, L. (2004). The effect of audit committee expertise, independence, and activity on aggressive earnings management. Auditing: A Journal of Practice \& Theory, 23(2), 13-35. http://dx.doi.org/10.2308/aud.2004.23.2.13

Boyle, E. J. (1993). A Framework for the Modern Internal Audit Function. Advances in Management Accounting, 2, 227-254.

Carcello, J., \& Neal, T. (2003). Audit Committee Characteristics and Auditor Dismissals Following New Going Concern Reports. Accounting Review, 78(1), 95-117. http://dx.doi.org/10.2308/accr.2003.78.1.95

Carslaw, C. A., \& Kaplan, S. E. (1991). An examination of audit delay: Further evidence from New Zealand. Accounting and Business Research, 22, 21-32. http://dx.doi.org/10.1080/00014788.1991.9729414

Chambers, A. E., \& Penman, S. H. (1984). Timeliness of reporting and the stock price reaction to earnings announcements. Journal of Accounting Research, 22(1), 21-47. http://dx.doi.org/10.2307/2490700

Courtis, J. K. (1976). Relationships between timeliness in corporate reporting and corporate attributes. Accounting and Business Research, 6(25), 45-56. http://dx.doi.org/10.1080/00014788.1976.9729085

Davies, B., \& Whittred, G. P. (1980). The association between selected corporate attributes and timeliness in $\begin{array}{lllll}\text { corporate } & \text { reporting: } & \text { Further }\end{array}$ http://dx.doi.org/10.1111/j.1467-6281.1980.tb00085.x

Fama, E. F., \& Jensen, M. C. (1983). Separation of ownership and control. Journal of Law and Economics, 


\section{6(2), 301-325. http://dx.doi.org/10.1086/467037}

Garsombke, H. P. (1981). The timeliness of corporate financial disclosure. In annual reports communication via Courtis, J. K. (Ed.), AFM Exploratory Series, No. 11. Armidale: University of New England.

Gilling, D. M. (1977). Timeliness in corporate reporting: Some further evidence comment. Accounting and Business Research, 8, 34-36. http://dx.doi.org/10.1080/00014788.1977.9729106

Givoly, D., \& Palmon, D. (1982). Timeliness of annual earnings announcements: Some empirical evidence. The Accounting Review, 57(3), 486-508.

Hair, J. K. Jr., Anderson, R. E., Tatham, R. L., \& Black, W. C. (1995). Multivariate Data analysis (3rd ed.). New York: Macmillian

Haron, H., Chambers, A., \& Ismail, R. R. (2004). The Reliance of external auditors on internal auditors Managerial Auditing Journal, 19(9), 1148-1159. http://dx.doi.org/10.1108/02686900410562795

Hashim, J., \& Abdul Rahman, R. (2011). Audit Report Lag the Effectiveness of Audit Committee Among Malaysian Listed Companies. International Bulletin of Business Administration, 10, 50-6.

Henderson, B. C., \& Kaplan, S. E. (2000). Research notes: An examination of audit report lag for banks: A panel data approach. Auditing: A Journal of Practice \& Theory, 19(2), 159-174. http://dx.doi.org/10.2308/aud.2000.19.2.159

Ishak, I., MuhamadSidek, A. S., \& Rashid, A. A. (2010). The Effect of company ownership on the timeliness of financial Reporting: Empirical evidence from Malaysia. UNITAR e-Journal, 6(2), 20-35.

Ismail, H., Mohd. Iskandar, T., \& MohidRahmat, M. (2008). Corporate reporting quality, audit committee and quality of audit. Malaysian Accounting Review, 7(1), 21-42.

Jaggi, B., \& Tsui, J. (1999). Determinants of audit report lag: Further evidence from Hong Kong. Accounting and Business Research, 30(1), 17-28. http://dx.doi.org/10.1080/00014788.1999.9728921

Kirk, D. J. (2000). Experience with the Public Oversight Board and corporate audit committees. Accounting Horizons, 14(1), 103-111. http://dx.doi.org/10.2308/acch.2000.14.1.103

Klein, A. (2002). Economics determinants of audit committee independence. Accounting Reviews, 77(2), 435-452. http://dx.doi.org/10.2308/accr.2002.77.2.435

Krishnan, J. (2005). Audit committee quality and internal control: An empirical analysis. The Accounting Review, 80(2), 649-675. http://dx.doi.org/10.2308/accr.2005.80.2.649

Lee, H. (2009). Do lengthy auditor tenure and the provision of non-audit services by the external auditor reduce audit report lags? International Journal of Auditing, 13, 87-104. http://dx.doi.org/10.1111/j.1099-1123.2008.00406.x

Leventis, S., Weetman, P., \& Caramanis, C. (2005). Determinants of audit report lag: Some evidence from the Athens Stock Exchange. International Journal of Auditing, 9(1), 45-58. http://dx.doi.org/10.1111/j.1099-1123.2005.00101.x

Listing Requirements Bursa Malaysia. (2009). Retrieved 1st January, 2012, from http://www.bursamalaysia.com.my

Malaysian Code of Corporate Governance. (2007). Retrieved from http://www.sc.com.my

Mohamad, N. S., \& Wan Hussin, W. N. (2010). Corporate Governance and Audit Report Lag in Malaysia. Asian Academy of Management Journal of Accounting and Finance, 6(2), 57-84.

Nelson, S. P., \& Shukeri, S. N. (2011). Corporate Governance and Audit Report Timeliness: Evidence from Malaysia. In S. Susela Devi \& Keith Hooper (Eds.), Accounting in Asia (Research in Accounting in Emerging Economies). Emerald Group Publishing Limited.

Newtown, J. D., Ashton, R. H., \& Graul, P. R. (1989). Audit delay and the timeliness of corporate reporting. Contemporary Accounting Research, 5(2), 657-673. http://dx.doi.org/10.1111/j.1911-3846.1989.tb00732.x

Ng, P. P. H., \& Tai, B. Y. K. (1994). An empirical examination of the determinants of audit delay in Hong Kong. British Accounting Review, 26(1), 43-59. http://dx.doi.org/10.1006/bare.1994.1005

Nunally, J. C. (1978). Psychology Theory (2nd ed.). New York: McGraw Hill.

Penno, M. (1990). Auditing for performance evaluation. Accounting Review, 2, 520-536. 
Raghunandan, K., Read, W. J., \& Rama, D. V. (2001). Audit Committee Composition, Gray Directors and Interaction with Internal Auditing. Accounting Horizons, 15(2). http://dx.doi.org/10.2308/acch.2001.15.2.105

Raja-Ahmad, R. A., \& Kamarudin, K. A. (2003). Audit delay and the timeliness of corporate reporting: Malaysian evidence. Paper presented at the Hawaii International Conference on Business Program.

Saleh, N., Iskandar, T., \& Rahmat, M. (2007). Audit committee characteristics and earnings management: evidence from Malaysia. Asian Review of Accounting, 15(2), 147-163. http://dx.doi.org/10.1108/13217340710823369

Spraakman, G. (1997). Transaction cost economics: a theory for internal audit. Managerial Auditing Journal, 12, 323-330. http://dx.doi.org/10.1108/02686909710180670

Stewart, J., \& Munro, L. (2007). The impact of audit committee existence and audit committee meeting frequency on the external audit: Perceptions of Australian auditors. International Journal of Auditing, 11(1), 51-69. http://dx.doi.org/10.1111/j.1099-1123.2007.00356.x

Tauringana, V., Kyeyune, M. F., \& Opio, P. J. (2008). Corporate governance, dual language reporting and the timeliness of annual reports on the Nairobi Stock Exchange. Research in Accounting in Emerging Economies, 8, 13-37.

Williamson, O. E. (1975). Markets and Hierarchies. New York: Free Press.

Yaacob, N., \& Che Ahmad, A. (2012). Adoption of FRS and Audit Delay in Malaysia. International Journal of Economics and Finance, 4(1), 167-176. http://dx.doi.org/10.5539/ijef.v4n1p167

\section{Copyrights}

Copyright for this article is retained by the author(s), with first publication rights granted to the journal.

This is an open-access article distributed under the terms and conditions of the Creative Commons Attribution license (http://creativecommons.org/licenses/by/3.0/). 